\title{
KONSEP PEMASARAN ISLAM DI BANK PEMBIAYAAN RAKYAT SYARIAH DI KABUPATEN TAPANULI SELATAN
}

\author{
Abdul Nasser Hasibuan \\ Institut Agama Islam Negeri Padangsidimpuan \\ Jalan T. Rizal Nurdin Km. 4,5 Sihitang, Padangsidimpuan \\ E-mail: abdulnasserhasibuan@yahoo.com
}

\begin{abstract}
ABSTRAK,
Penelitian ini membahas mengenai konsep pemasaran Islam yang dilakukan oleh PT. Bank Pembiayaan Rakyat Syariah (BPRS) se-kabupaten Tapanuli Selatan yang terdiri dari PT. Bank Pembiayaan Rakyat Syariah (BPRS) Oloan Ummah Sidempuan, Bank Pembiayaan Rakyat Syariah (BPRS) Mitra Manindo Panyabungan, Bank Pembiayaan Rakyat Syariah (BPRS) Sindanglaya Kotanopan. Tujuan penelitian ini adalah untuk mengetahui perencanaan strategi pemasaran produk funding di PT. Bank Pembiayaan Rakyat Syariah (BPRS) secara langsung implementasi strategi pemasaran produk. Penelitian ini menggunakan metode kualitatif deskriftif. Hasil dari penelitian ini adalah Implementasi strategi pemasaran PT. BPRS yaitu promosi secara berkelanjutan dengan jangka waktu yang relatif singkat, kemudian penerapan harga yang relatif murah dibandingkan dengan bank syariah lainnya, yaitu bank tidak mengenakan biaya administrasi pada rekening tabungan. PT. Bank Pembiayaan Rakyat Syariah (BPRS) juga memberikan layanan fasilitas jemput bola untuk nasabah tabungan maupun nasabah pembiayaan.
\end{abstract}

Kata kunci : Konsep Pemasaran Islami, Bauran Pemasaran, Implementasi Pasar

\section{ABSTRACT,}

This study discusses the concept of Islamic marketing conducted by PT. Islamic People's Financing Bank (BPRS) in South Tapanuli regency consisting of PT. Sharia People's Financing Bank (BPRS) Oloan Ummah Sidempuan, Sharia People's Financing Bank (BPRS) Mitra Manindo Panyabungan, Sharia People's Financing Bank (BPRS) Sindanglaya Kotanopan. The purpose of this study was to determine the funding strategy of marketing product planning at PT. Islamic People's Financing Bank (BPRS) directly implements product marketing strategies. This study uses descriptive qualitative methods. The results of this study are the implementation of the marketing strategy of PT. SRB is a continuous promotion with a relatively short period of time, then the application of a relatively cheap price compared to other Islamic banks, namely banks do not charge administrative fees on savings accounts. PT. The Syariah People's Financing Bank (BPRS) also provides pick-up facilities for savings customers and financing customers.

Keywords: Islamic Marketing Concept, Marketing Mix, Market Implementation 


\section{PENDAHULUAN}

Perkembangan ekonomi Islam di Indonesia boleh dikatakan mengalami perkembangan yang cukup pesat. Dilihat dari segi kedudukan dan perannya, lembaga keuangan syariah di Indonesia memiliki landasan hukum yang kuat sehingga dapat memberi peran yang maksimal dan memberi daya tawar positif untuk mempercepat pertumbuhan ekonomi nasional (Herry Sutanto dan Khaerul Umam, 2017).

Perusahan masa kini tidak bergerak dalam pasar dengan saingan yang sudah diketahui dan sudah pasti, atau pilihan pelanggan yang stabil, melainkan dalam perang antara saingan yang terus berubah, kemajuan teknologi, hukum baru, kebijaksanaan perdagangan yang terkelola dan turunnya kesetiaan pelanggan. Karena itu tidak heran bahwa perusahaan yang unggul masa kini adalah yang paling berhasil memuaskan, bahkan menyenangkan pelanggan sasaran mereka. Perusahaan-perusahaan ini melihat pemasaran sebagai filosofi seluruh perusahaan, bukan bagian tersendiri (Philip Kotler dan A.B. Susanto, 1999).

Cepatnya informasi yang masuk akibat majunya teknologi sektor informasi seperti televisi, radio, koran atau majalah telah menjadikan masyarakat semakin cerdas. Oleh karena itu, kemajuan teknologi ini dimanfaatkan sebesar-besarnya untuk merebut hati nasabah agar menggunakan jasanya hanya melalui pemahaman pemasaran secara utuh dengan menjalankan strategi pemasaran yang tepat(Philip Kotler dan A.B. Susanto).

Strategi ini dikenal dengan nama bauran pemasaran (marketing mix) (Kasmir,4). Dengan strategi ini masyarakat mau menanamkan dananya dalam bentuk simpanan. Karena perkembangan dan pertumbuhan dunia perbankan akan sangat dipengaruhi oleh kemampuannya dalam menghimpun dana masyarakat, baik skala kecil maupun besar dengan masa pengendapan yang memadai. Sebagai lembaga keuangan masalah bank yang paling utama adalah dana. Tanpa dana yang cukup, bank tidak dapat berfungsi sama sekali (Nurul Huda dan Mohamad Heykal, 86). Dari latar belakang tersebut, penulis tertarik untuk mengadakan penelitian, Bagaimana implementasi strategi pemasaran produk di PT. Bank Pembiayaan Rakyat Syariah (BPRS).

\section{LANDASAN TEORI}

\section{Konsep Pemasaran Dalam Islam}

Konsep dasar spiritualisasi marketing adalah tata olah cipta , rasa, hati karsa (implementasi) yang dibimbing oleh integrasi keimanan, ketakwaan, dan ketaatan kepada syariat Allah SWT. Jika iman, takwa, dan taat syariat ini semu, maka aktivitas 
marketing yang dilakukan itu tidak ada sangkut pautnya dengan syariat Islam. Dalam Al-Quran dan hadis kita dapat melihat bagaimana ajaran Islam mengatur kehidupan bisnis (pemasaran) seorang muslim seperti dalam Q.S.An-Nisaa`ayat 29

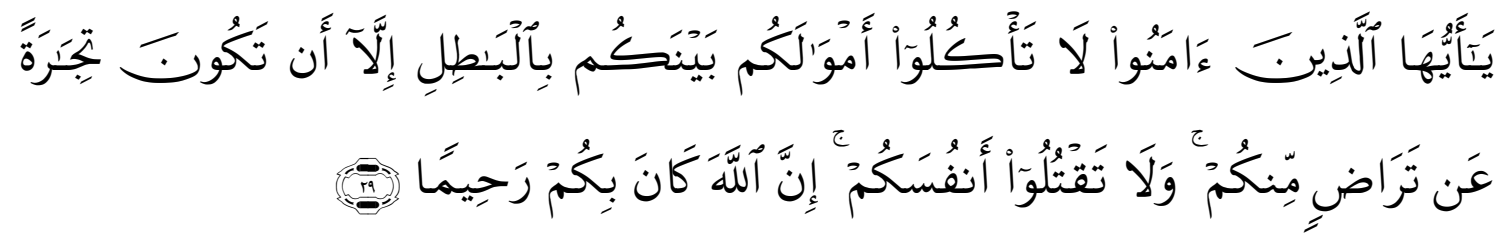

Artinya: Hai orang-orang yang beriman, janganlah kamu saling memakan harta sesamamu dengan jalan yang batil, kecuali dengan jalan perniagaan yang Berlaku dengan suka sama-suka di antara kamu. dan janganlah kamu membunuh dirimu. Sesungguhnya Allah adalah Maha Penyayang kepadamu. (Q.S.An-Nisaa $:$ 29) (Departemen Agama RI, 122)

Dari ayat tersebut memberikan penjelasan mengenai konsep pemasaran yang berorientasi syariah Islam yaitu kalimat janganlah kamu saling memakan harta sesamamu dengan cara batil, artinya kebutuhan dan keinginan untuk memperoleh produk (permintaan) tidak diperoleh dengan cara batil (bohong, tipu, rampok, curi dan korupsi). Kemudian pada kalimat kecuali dengan suka sama suka artinya bahwa untuk memperolehnya harus dilakukan melalui pertukaran ( barang dari marketeruang dari konsumen) proses pertukaran unit ( barang dan uang) inilah transaksi yang dilakukan dengan suka sama suka (Ali Hasan, 12-13). Dalam Q.S At- Thaahaa ayat 44 juga dijelaskan mengenai sikap dan etika dalam bertransaksi yaitu

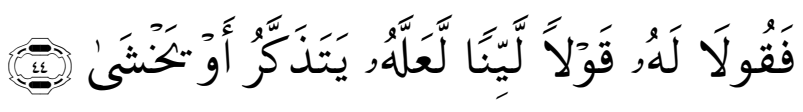

Artinya: Maka berbicaralah kamu berdua kepadanya dengan kata-kata yang lemah lembut, Mudah-mudahan ia ingat atau takut. (Q.S At- Thaahaa :44) (Departemen Agama RI, 480)

Kemudian dalam hadis riwayat Bukhari yaitu Allah akan memberikan rahmatnya pada setiap orang yang bersikap baik ketika menjual, membeli dan membuat suatu pernyataan (Ali Hasan, 12-13). Dari beberapa ayat dan hadis di atas telah sangat jelas bahwa segala sesuatunya telah diatur di dalam syariah Islam termasuk konsep pemasaran.

Ada empat karakteristik syariah marketing yang dapat menjadi panduan bagi para pemasar yaitu: 
Pertama, teistis ( Rabbaniyyah), salah satu ciri khas syariah marketing yang tidak dimiliki dalam pemasaran konvensional yang dikenal selama ini adalah sifatnya yang religius (diniyyah)

Kedua, etis (akhlaqiyyah, keistimewaan lain dari syariah marketing, selain karena teistis (rabbaniyyah), juga karena ia sangat mengedepankan masalah akhlak (moral dan etika) dalam seluruh aspek kehidupannya

Ketiga, Realistis (al-waqi ‘yyah), syariah marketing bukanlah konsep yang eksklusif, fanatis, anti modernitas, dan kaku. Syariah marketing adalah konsep pemasaran yang fleksibel, sebagaimana keluasan syariah islamiah yang melandasinya.

Keempat, Humanistis (al-insaniyyah), keistimewaan syariah marketing yang lain adalah sifatnya yang humanistis universal. Yaitu mencakup sifat kemanusiaan secara keseluruhan (Herry Sutanto dan Khaerul Umam, 65).

Selain dari empat kharakteristik di atas ada juga sembilan etika pemasaran yang menjadi prinsip-prinsip bagi pemasaran syariah dalam menjalankan fungsi-fungsi pemasaran yaitu:

Satu, Memiliki kepribadian spiritual (takwa)

Dua, Berperilaku baik dan simpatik (shidq)

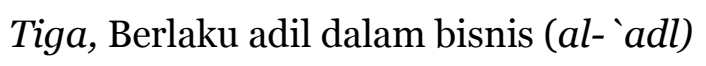

Empat, Bersikap melayani dan rendah hati (khidmah)

Lima, Menepati janji dan tidak curang

Enam, Jujur dan terpercaya (al-amanah)

Tujuh, Tidak suka berburuk sangka

Delapan, Tidak suka menjelek-jelekkan (ghibah)

Sembilan, Tidak melakukan sogok/suap (risywah). (Herry Sutanto dan Khaerul Umam, 65)

\section{Bauran Pemasaran (Marketing Mix)}

Bauran pemasaran (marketing mix) merupakan strategi kombinasi yang dilakukan oleh berbagai perusahaan dalam bidang pemasaran. Hampir semua perusahaan melakukan strategi ini guna mencapai tujuan pemasarannya, apalagi dalam kondisi persaingan yang demikian ketat pada saat ini.

Kombinasi yang terdapat dalam komponen marketing mix harus dilakukan secara terpadu. Artinya, pelaksanaan dan penerapan komponen ini harus dilakukan dengan 
memperhatikan antara satu komponen dengan komponen lainnya. Karena antara satu komponen dengan komponen lainnya saling berkaitan erat guna mencapai tujuan perusahaan dan tidak efektif jika dijalankan sendiri-sendiri.

Penggunaan bauran pemasaran (marketing mix) dalam dunia perbankan dilakukan dengan menggunakan dengan konsep-konsep yang sesuai dengan kebutuhan bank (Kasmir, 119-120). Untuk meningkatkan kualitas layanan bank, CEO/marketer dapat menggunakan strategi pelanyanan P-Seven model $(7 \mathrm{P})$. Penggunaan konsep bauran pemasaran untuk produk jasa terdapat $7 \mathrm{P}$ yaitu: produk (product), harga (price), tempat/saluran distribusi (place), promosi (promotion), orang (people), bukti fisik (physical evidence), dan proses (process).

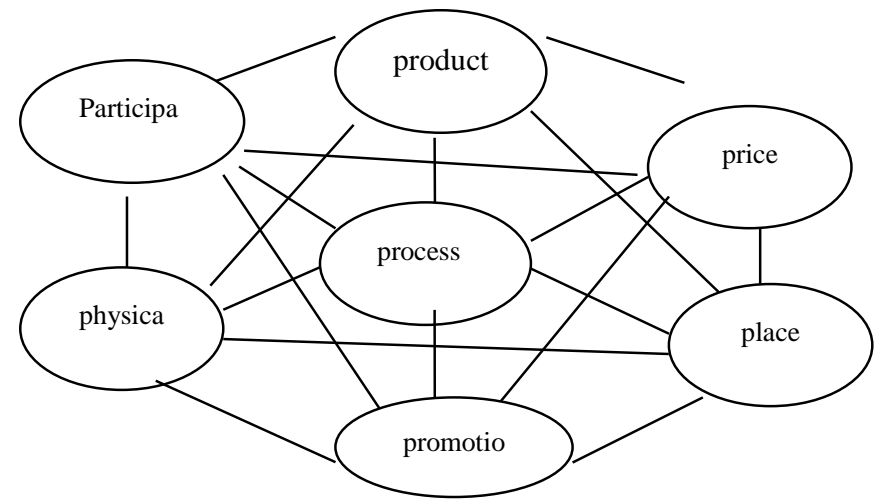

Gambar 1.Kerangka model strategi layanan $7 \mathbf{P}$

Proses perbaikan layanan secara terus menerus diperlukan untuk tiga alasan yaitu menarik dan mempertahankan pelanggan, daya tahan bersaing di pasar, dan perubahan selera pasar akibat perubahan lingkungan.

\begin{tabular}{|c|c|c|}
\hline No & strategi & Isu-isu program \\
\hline \multirow{5}{*}{1} & \multirow{5}{*}{ Process } & $\begin{array}{l}\text { Rincian standar prosedur operasi ,manual dan deskripsi } \\
\text { kerja }\end{array}$ \\
\hline & & Prosedur solusi masalah/komplain nasabah \\
\hline & & Standar kinerja layanan (manusia dan teknologi) \\
\hline & & Keterlibatan interfungsional \\
\hline & & Tingkat just in time delivery-lend times deliveries \\
\hline \multirow{3}{*}{2} & \multirow{3}{*}{ Product } & Pengembangan variasi produk \\
\hline & & Spesifikasi kualitas \\
\hline & & $\begin{array}{l}\text { Model /tampilan/ukuran kemasan kartu manual/kartu } \\
\text { EFT }\end{array}$ \\
\hline
\end{tabular}




\begin{tabular}{|c|c|c|}
\hline & & Logo, merek dagang, dan persepsi nasabah/publik \\
\hline & & Layanan pendukung dan komplementer \\
\hline & & Model layanan: full service, sell service \\
\hline & \multirow{4}{*}{ Price } & Analisis kompetitif \\
\hline & & Penetapan tingkat harga, perubahan harga, target pasar,dll \\
\hline 3 & & Potongan provisi, hadiah, kebijakan penjualan \\
\hline & & Metode/cara/sistem kredit \\
\hline \multirow{5}{*}{4} & \multirow{5}{*}{$\begin{array}{l}\text { Place- } \\
\text { channel }\end{array}$} & Rencana saluran (tambahan baru mandiri, ATM bersama) \\
\hline & & Manajemen saluran, alokasi penempatan produk \\
\hline & & Derajat integrasi saluran \\
\hline & & Kebijakan dan standar (tingkat) layanan \\
\hline & & Kenyamanan, keamanan, (lokasi) dan fasilitas \\
\hline \multirow{4}{*}{5} & \multirow{4}{*}{ Promotion } & $\begin{array}{l}\text { Periklanan: anggaran, target pasar, media yang } \\
\text { digunakan,dll }\end{array}$ \\
\hline & & $\begin{array}{l}\text { Penjualan :coorporate banking dan costumer retail } \\
\text { banking }\end{array}$ \\
\hline & & Market share, posisi produk - pasar \\
\hline & & Brand position \\
\hline \multirow{4}{*}{6} & \multirow{4}{*}{$\begin{array}{l}\text { Physical } \\
\text { evidence }\end{array}$} & $\begin{array}{l}\text { Tampilan gedung, tata ruang dan tata letak fasilitas } \\
\text { layanan }\end{array}$ \\
\hline & & Penerangan, dekorasi dan kebersihan \\
\hline & & Counter layanan transaksi manual dan otomatic (ATM) \\
\hline & & $\begin{array}{l}\text { Daya tarik, kenyamanan, kemudahan akses, dan tempat } \\
\text { parker }\end{array}$ \\
\hline \multirow{4}{*}{7} & \multirow{4}{*}{$\begin{array}{l}\text { Participan } \\
\text { ts }\end{array}$} & Pelatihan skill interaksi dan resolusi masalah nasabah \\
\hline & & Sistem dan prosedur imbal jasa untuk mobilitas kerja \\
\hline & & Prosedur partisipasi team layanan dan eksekusi layanan \\
\hline & & $\begin{array}{l}\text { Keterikatan norma-norma religious \& norma objektif } \\
\text { universal }\end{array}$ \\
\hline
\end{tabular}

Tabel 1 Strategi Layanan Seven P (Ali Hasan, 136-137)

\section{METODOLOGI PENELITIAN}

Penelitian ini menggunakan analisis deskriptif yaitu mencatat secara teliti segala gejala (fenomena) yang dilihat dan didengar serta dibacanya (via wawancara, atau bukan, catatan lapangan, foto, video, dokumen pribadi, catatan atau memo, 
dokumen resmi atau bukan, dan lain-lain) (Burhan Bungin, 93). Tujuan dari penelitian deskriptif adalah untuk membuat gambaran secara sistematis, faktual, dan akurat mengenai fakta-fakta dan sifat-sifat populasi atau daerah tertentu (Sumadi Suryabrata, 75).

\section{Subjek Penelitian}

Dalam penelitian kualitatif ini, sampel sumber data menggunakan teknik purposive sampling yaitu dipilih dengan mempertimbangkan dan tujuan tertentu (Sugiyono, 391). Sampel sebagai sumber data atau sebagai informan adalah mereka yang tergolong masih terlibat dalam kegiatan yang sedang diteliti, memiliki waktu yang memadai untuk dimintai informasi, menguasai dan memahami kegiatan yang sedang diteliti, serta dipercaya memberikan informasi yang akurat. Yang menjadi informan dalam penelitian ini adalah Bagian Operasional, custemer service, Account Officer PT Bank Pembiayaan Rakyat Syariah (BPRS).

\section{Teknik analisis data}

Penelitian ini dilakukan dalam bentuk deskriptif kualitatif yaitu penelitian yang berusaha menggambarkan dan menginterpretasikan objek sesuai dengan apa adanya dan sering disebut dengan penelitian non eksperimen. Maka proses analisis data yang digunakan adalah analisis data kualitatif dalam bentuk deskriptif.

Analisis data dilakukan dengan menggunakan langkah-langkah sebagai berikut:

Pertama, Menelaah seluruh data yang tersedia dari sumber data

Kedua, Mengadakan reduksi data yang dilakukan dengan jalan membuat abstraksi

Ketiga, Menyusun dalam satuan-satuan dan kemudian dikategorisasikan pada langkah berikutnya

Keempat, Mengadakan pemeriksaan keabsahan data dengan derajat kepercayaan (credibility), keteralihan (transferability), kebergantungan (dependability), dan kepastian (confirmability).

Kelima, Menafsirkan data menjadi teori substantive dengan menggunakan metode analisis komparatif.

Setelah semua langkah-langkah diatas dilaksanakan maka data yang terkumpul dideskripsikan secara sistematis sehingga masalah yang dibahas dapat dipahami menjadi suatu konsep yang utuh. Dengan demikian metode analisis data yang dilaksanakan menggunakan metode berpikir induktif (Lexy J. Moleong, 190). 


\section{PEMBAHASAN HASIL PENELITIAN}

\section{Perencanaan Strategi Pemasaran Produk di PT. Bank Pembiayaan Rakyat Syariah (BPRS)}

Perusahaan yang ingin tetap bertahan di dunia bisnis akan selalu melakukan pemasaran yang menggunakan ciri khasnya masing-masing. Tidak ada satu perusahaan pun yang tidak memiliki strategi pemasaran. Perusahaan yang baik tahu bagaimana caranya beradaptasi dengan pasar yang selalu berubah-ubah dengan cara membuat perencanaan yang sering disebut dengan rencana pemasaran.

\section{Implementasi Strategi Pemasaran Produk di PT. Bank Pembiayaan Rakyat Syariah (BPRS)}

Strategi yang brilian, program yang cerdas, dan kejelian implementasi merupakan syarat penting untuk keberhasilan pemasaran produk, tidak terkecuali pada produk-produk perbankan yang ditawarkan. Tanpa pelaksanaan yang tepat, rencana yang telah dibuat menjadi tidak efektif lagi. Implementasi menjadi langkah yang penting dalam perencanaan pemasaran. Dan implementasi rencana tersebut yang menentukan hasil dari perencanaan yang telah disusun di awal.

Sebuah rencana pelaksanaan yang efektif menunjukkan kegiatan apa yang harus dilaksanakan, lokasi pelaksanaannya, dan bagaimana pelaksanaan itu akan dilakukan (Ali Hasan, 236). Salah satu konsep yang dapat diterapkan dalam implementasi pemasaran produk Perbankan Syariah khususnya pada produk funding di PT. BPRS adalah bauran pemasaran atau biasa dikenal dengan marketing mix dengan menggunakan strategi ${ }_{7} \mathrm{P}$ yaitu produk (product), harga (price), tempat/saluran distribusi (place), promosi (promotion), orang (people), bukti fisik (physical evidence), dan proses (process). Pemasaran Produk penghimpunan dana ini menjadi tantangan tersendiri bagi PT. BPRS mengingat bahwa bank ini berorientasi pada pembiayaan. Namun tidak menutup kemungkinan bahwa produk dapat berkembang di PT. BPRS. 
Volume 6 Nomor 2 Ed. Juli-Desember 2018: hal. 19-30 p-ISSN: 2356-4628 e-ISSN : 2579-8650

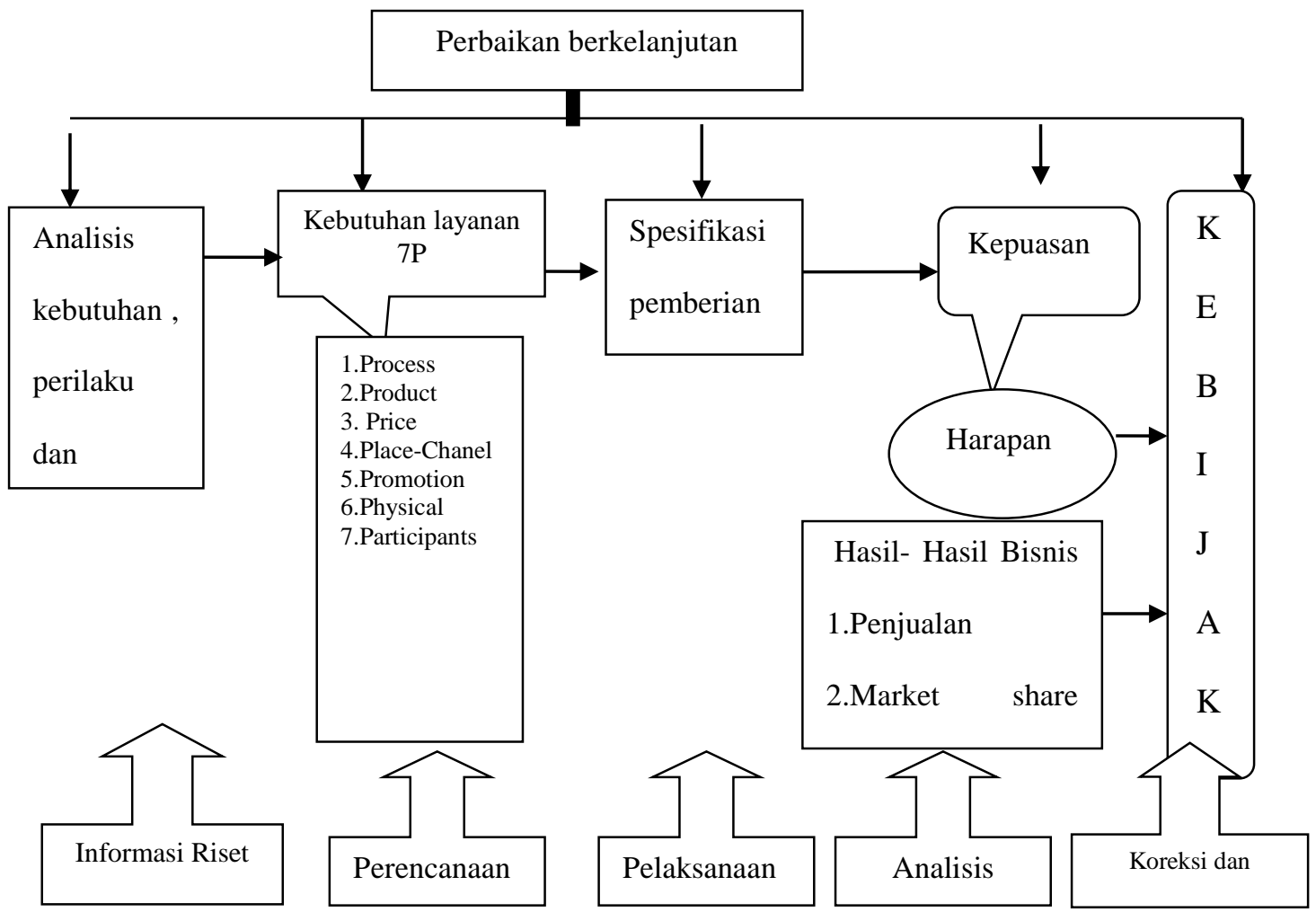

Gambar 4. Proses Implementasi Layanan Produk Bank

Dalam pelaksanaannya PT BPRS lebih mengutamakan strategi promosi dalam pemasaran produk mereka. Dan lebih menekankan pada biaya administrasi yang tidak dikenakan pada produk Tabungan IB Ummah yang mereka tawarkan. Dalam sistem pelanyanan mereka menggunakan taktik jemput bola untuk mempermudah nasabah (Dedi Ekha Putra, 2014). Dimana apabila nasabah ingin menyetor tabungan atau deposito namun tidak memiliki waktu untuk datang ke bank maka dapat menghubungi pihak bank untuk menjemput setoran tersebut.

Pada dasarnya strategi pemasaran yang digunakan pada produk tabungan dan deposito yang ada di PT Bank Pembiayaan Rakyat Syariah itu sama, yaitu strategi yang digunakan dengan menggunakan bauran pemasaran produk jasa, atau biasa dikenal dengan $7 \mathrm{P}$ dengan rincian sebagai berikut:

Pertama, Produk (Product)

Produk penghimpunan dana yang ditawarkan oleh PT Bank Pembiayaan Rakyat Syariah adalah produk tabungan IB Ummah dan deposito IB Ummah (Meria Andelina Simamora, 2014). Dengan menawarkan kepada masyarakat bahwa menabung dan mendepositokan uang memiliki banyak manfaat. Sistem bagi hasil yang di tetapkan bank pada akhir bulan April 2014 sebesar 30:70 untuk deposito jangka waktu 
1-3 bulan dan 40:60 untuk deposito jangka waktu 6 bulan dan 12 bulan (Meria Andelina Simamora, 2014).

Kedua, Harga (Price)

Dari harga tabungan yang di tetapkan oleh bank dapat memenuhi kriteria kebutuhan nasabah sehingga menarik minat para nasabah untuk menabung di bank tersebut. Namun untuk produk deposito, harga yang ditawarkan oleh pihat bank masih belum dapat menarik minat nasabah untuk berinvestasi. Hal ini disebabkan jumlah untuk mendapatkan bagi hasil yang khusus terlalu tinggi sehingga sampai saat ini realisasinya belum ada.

Ketiga, Promosi ( promotion)

Meskipun promosi dilakukan, masih ada juga sebagian orang di lingkungan sekitar bank yang belum mengetahui tentang PT BPRS (Shelly, 2014). Hal ini di akibatkan oleh frekuensi promosi yang terlalu singkat dan promosi tersebut tidak sampai pada semua daerah sasaran.

Keempat, Tempat (Place)

Secara geografis PT BPRS di Tapanuli Selatan, sangat strategis karena semua letaknya yang berada di pusat kota dan dekat dengan pusat kegiatan masyarakat, seperti pasar dan pertokoan. Meskipun letaknya yang strategis, tapi masih ada kekurangan yang membuat nasabah kurang suka dengan bank tersebut. Karena bersebelahan dengan ruko-ruko sehingga tidak terlihat seperti bank pada umumnya, kemudian letaknya yang berada di dekat parkiran kendaraan roda dua kurang nyaman bila dilihat (Firda Sari Lubis, 2014).

Kelima, Orang (People)

Seluruh karyawan di PT BPRS sebelum bekerja mengikuti kegiatan tranning atau pelatihan (Meria Andelina Simamora, 2014). Dalam proses pelayanan kepada nasabah karyawan menggunakan pakaian yang telah di tetapkan oleh bank sehingga terlihat seragam dan rapi. Sikap karyawan dalam melayani nasabah juga memberikan pelayaan yang prima sesuai dengan standar pelayanan bank seperti salam, sapa, senyum dan lain sebagainya.

Keenam, Proses (Process)

Proses untuk membuka rekening tabungan memudahkan nasabah dalam membuka rekening karena setoran awalnya yang cukup murah dan persyaratan yang tidak rumit (Alamsyah, 2014). 
Ketujuh, Bukti fisik (physical evidence),

Berdasarkan observasi selama penelitian, tata ruangan yang disediakan bank untuk nasabah sangat sempit, Dibandingkan dengan bank-bank lainnya yang menjadi hambatan yang paling signifikan bagi bank adalah tidak adanya fasilitas ATM, transaksi online dan transfer. Di era globalisasi saat sekarang ini fasilitas seperti itu bukan menjadi hal yang baru lagi, bahkan sudah menjadi kebutuhan sehari- hari.

\section{KESIMPULAN}

Implementasi strategi pemasaran produk di PT. Bank Pembiayaan Rakyat Syariah (BPRS) yaitu promosi secara berkelanjutan dengan jangka waktu yang relatif singkat, kemudian penerapan harga yang relatif murah dibandingkan dengan bank syariah lainnya, yaitu bank tidak mengenakan biaya administrasi pada rekening tabungan. PT. Bank Pembiayaan Rakyat Syariah (BPRS) memberikan layanan fasilitas jemput bola untuk nasabah tabungan maupun nasabah pembiayaan.

\section{DAFTAR PUSTAKA}

Ali, Zainuddin, Hukum Perbankan Syariah, Jakarta: Sinar Grafika,20o8

Bungi, Burhan, Metodologi Penelitian Kualitatif Aktualisasi Metodologis ke Arah Ragam Varian Kontemporer, Jakarta: PT Raja Grafindo Persada, 2010

Darmawi, Herman, Pasar Finansial dan Lembaga-lembaga Finansial, Jakarta: PT Bumi Aksara,2006

Hasan, Ali, Marketing Bank Syariah, Bogor: Ghalia Indonesia, 2010

Hasibuan, Melayu S.P, Dasar-Dasar Perbankan. Jakarta:PT. Bumi Aksara, 2009

Huda, Nurul dan Mohamad Heykal, Lembaga Keuangan Islam: Tinjauan Teoritis dan Praktik, Jakarta: Kencana,2010

Karim, Adiwarman, Bank Islam: Analisis Fiqh dan Keuangan Jakarta: Rajawali Pers, 2009

Kasmir, Manajemen Perbankan Jakarta: Rajawali Pers, 2008

Kotler, Philip dan A.B. Susanto, Manajemen pemasaran di Indonesia, Jakarta: Salemba Empat, 1999

Laksana, Fajar, Manajemen Pemasaran, Yogyakarta: Graha Ilmu, 2008

Mangani, Ktut Silvanita, Bank dan Lembaga Keuangan Lain, Jakarta: Erlangga,2009

M. Mursid, Manajemen Pemasaran Jakarta :PT Bumi Aksara, 2008 
Sunarto, Zulkifli, Panduan Praktis Transaksi Perbankan Syariah, Jakarta: Zikrul Hakim,2003

Shonhaji, Abdullah, dkk, Terjemahan Sunan Ibnu Majah Jilid III, Semarang: CV. Asy Syifa, 1993

Triandaru, Sigit dan Totok Budisantoso, Bank dan Lembaga Keuangan Lainnya, Jakarta: Salemba Empat,2008

Wirdyaningsih, Dkk, Bank dan Asuransi Islam Di Indonesia, Jakarta: Kencana, 2005 